\title{
Environmental effects on nutritive value of equine pastures in Northern Virginia
}

\author{
Tania A. Cubitt', W. Burton Staniar', David S. Kronfeld', Bridgett M. Byrd' and Patricia A. Harris² \\ Department of Animal and Poultry Science, Virginia Polytechnic Institute and State University, Blacksburg, Virginia, USA' and Equine Studies Group, \\ WALTHAM Centre for Pet Nutrition, Melton Mowbray, U.K.²
}

\begin{abstract}
Summary
The nutrient composition of pastures is described in relation to seasonal patterns of temperature (TP) and day length (DL). The seasonal patterns of TP and DL can be accurately characterized with a simple sine wave equation. The four parameters of the sine wave equation provide usable information about the variable being examined. Crude protein (CP), digestible energy (DE), and non-structural carbohydrates (NSC) peaked in the spring and fall months and acid detergent fiber (ADF) and neutral detergent fiber (NDF) peaked in the summer and winter months. Horse owners can utilize descriptions of the seasonal patterns in forage nutrient composition to avoid high NSC contributing to metabolic disorders such as laminitis or to take advantage of high CP for broodmares in early lactation and growing foals.
\end{abstract}

Keywords: nutrition, day length, temperature, pasture composition, Virginia

\section{Umwelteinflüsse auf den Futter- und Nährwert von Pferdeweiden}

Die Nährstoffgehalte von Weideaufwuchs werden hinsichtlich der Beziehung zur Umgebungstemperatur (TP) und Tageslänge (DL) überprüft. Die saisonale Verteilung der beiden Größen TP und DL kann präzise mit einfachen Modellen für Sinuskurven charakterisiert werden. Die notwendigen vier Parameter der Gleichung für die Sinuskurven liefern verwertbare Informationen über die untersuchten Variablen. Für die sich über 5 Jahre erstreckenden Untersuchungen standen 12 Hektar Weideflächen (Middleburg, Virginia) zur Verfügung mit den Hauptbestandteilen Poa pratensis, Trifolium repens und Festuca arundinacea. Die Grasproben wurden manuell 2-3 cm oberhalb des Bodens geschnitten, getrocknet und nach Standardverfahren analysiert; die Nicht-Gerüstkohlenhydrate (NSC) wurden rechnerisch abgeleitet: NSC $=100-($ Wasser+Rohprotein (CP) + Rohett+Rohasche+neutrale Detergentienfasern (NDF)). Daten zur Tagenslänge (h) wurden den Auf-

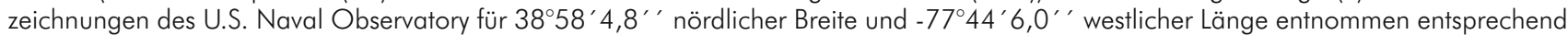
der geographischen Lage der Weideflächen. Daten zur durchschnittlichen Tagestemperatur und zum Niederschlag wurden vom National Climatic Data Center, Washington Dulles International Airport, etwa 27 Kilometer nordöstlich von Middleburg gelegen, bereitgestellt. Die Daten wurden mittels SAS-Statistiksoftware bearbeitet. Die höchsten Werte für CP, verdauliche Energie (DE) und NSC fallen in die Frühjahrsund Herbstmonate. Die Maxima für die sauren und neutralen Detergentienfasern liegen in den Sommer- sowie Wintermonaten. Für die Pferdehaltung können die Beschreibungen und Modelle zur saisonalen Variation der Zusammensetzung und des Energiegehaltes des Weideaufwuchses dazu dienen, die Nutzung etwa durch Pferde mit hohem Proteinbedarf wie laktierende Stuten oder wachsende Fohlen zu optimieren, oder um auch mögliche Risiken für bestimmte Tiergruppen beispielsweise durch hohe Gehalte an löslichen Kohlenhydraten zu meiden.

Schlüsselwörter: Fütterung, Tageslänge, Temperatur, Weide, Virginia

\section{Introduction}

About $80 \%$ of the horses in Virginia receive all or part of their nutrition from pasture (NAHMS 1998). Pasture is an inexpensive source of nutrients for horses when compared with purchased feeds such as complete feed mixes, grains, hay, chaff etc. Well managed pasture can provide most of the energy, protein and fiber needs of most horses. It is important to note that pasture itself is a living commodity and therefore its biochemical makeup is constantly changing in response to changes in the environment for example; photoperiod, temperature and rainfall. Therefore, it is important to evaluate changes in pasture composition and nutritive value in changing seasons. This variation, along with estimates of animal needs, will indicate when supplementation may assist meeting performance goals.
Previous studies of pastures at the Middleburg Agricultural Research and Extension Center (MAREC) have evaluated the nutrient content of the pastures in relation to equine growth and reproduction (Kronfeld et al. 1996, Cubitt 2004). These studies revealed deficiencies in some nutrients in relation to requirements of growing horses and broodmares in particular $\mathrm{Zn}, \mathrm{Cu}$, $P$ and Se (NRC 1989). The seasonal patterns of nutrients were recognized but not specifically quantified (Wilson et al. 1997). Seasonal variation in pasture composition occurs due to changes growth and maturity of the plant, which partially depend on the environment and their interactions with the environment. Forage plants decline in nutritional value as they advance in maturity (Fick et al. 1994). Perturbations in nutritive value of pastures is a potential putative cause of several equine health related issues including colic (French et al. 2005), and laminitis (Longland et al. 1999). The objectives of this study were to 
quantify the nutritive value of equine pastures and to test for relationships between environmental status and pasture nutritive value.

\section{Materials and Methods}

Four 12-ha pastures sown with Kentucky bluegrass (Poa pratensis), white clover (Trifolium repens), and tall fescue (Festuca arundinacea) at the MAREC were sampled monthly over a 5 yr period from 1998 to 2002. Samples were randomly collected by driving in a W-shaped pattern, stopping every $20 \mathrm{~m}$ throughout each field. Forage was cut using hand held clippers, a fistful of forage was grasped and cut 2 to $3 \mathrm{~cm}$ above the ground. Pasture samples were then dried, weighed, and submitted for proximate and mineral analysis (Dairy One DHIA Laboratory, Ithaca, NY). Non-structural carbohydrate (NSC) analysis done by Dairy One DHIA Laboratory includs starches, sugars, fructans, pectins, gums and mucilages in the proximate fraction which is determined by difference: NSC = $100-$ (water + CP + Fat + Ash + NDF) (Byrd 2005).

Day lengths were taken from U.S. Naval Observatory tables for latitude of $38^{\circ} 58^{\prime} 4.8^{\prime \prime} \mathrm{N}$, and longitude of $-77^{\circ} 44^{\prime} 6.0^{\prime \prime} \mathrm{W}$, which corresponds to the Middleburg area. Average daily temperature and rainfall were recorded at the National Climactic Data Center, Washington Dulles International Airport, which is approximately $27 \mathrm{~km}$ north-east from Middleburg.

Pearson correlations were used as tests of association between environmental and pasture data. Particular relationships between nutrients or DE and environmental conditions were described with quadratic equations. Sine wave equations were used to describe seasonal patterns in the data. (SAS Institute Inc., Cary, NC).

\section{Results}

Average daily ambient temperature as expected followed a similar pattern to day length with a peak in June and July and a low point in December and January. Sine wave equations were fit to the seasonal patterns of temperature $\left(R^{2}=0.96\right)$ and day length $\left(R^{2}=0.97\right.$, figure 1$)$.

Sine wave equations were then used to describe seasonal fluctuations in the following pasture composition variables;
$C P\left(R^{2}=0.34\right), D E\left(R^{2}=0.23\right)$, ADF $\left(R^{2}=0.34\right), N D F$ $\left(R^{2}=0.34\right), N S C\left(R^{2}=0.15\right)$ (figure 2). Parameters for the sine wave models are specified in table 1, where baseline describes the mean level of a variable and amplitude describes the variation in that variable. Frequency reflects periodthe range of $X$ values for a complete cycle. Offset represents horizontal phase shift, the point at which a sine wave begins relative to its mean.

Non structural carbohydrates were negatively correlated with fiber content in the pasture, ADF $(r=-0.20, P=0.005)$ and NDF $(r=-0.47, P<0.0001)$.

Quadratic regressions described relationships between ambient temperature and $C P\left(R^{2}=0.20, P<0.001\right), D E\left(R^{2}\right.$ $=0.11, P<0.001)$ (figure2), and fiber $\operatorname{ADF}\left(R^{2}=0.20\right)$, and $\operatorname{NDF}\left(R^{2}=0.23\right)$.
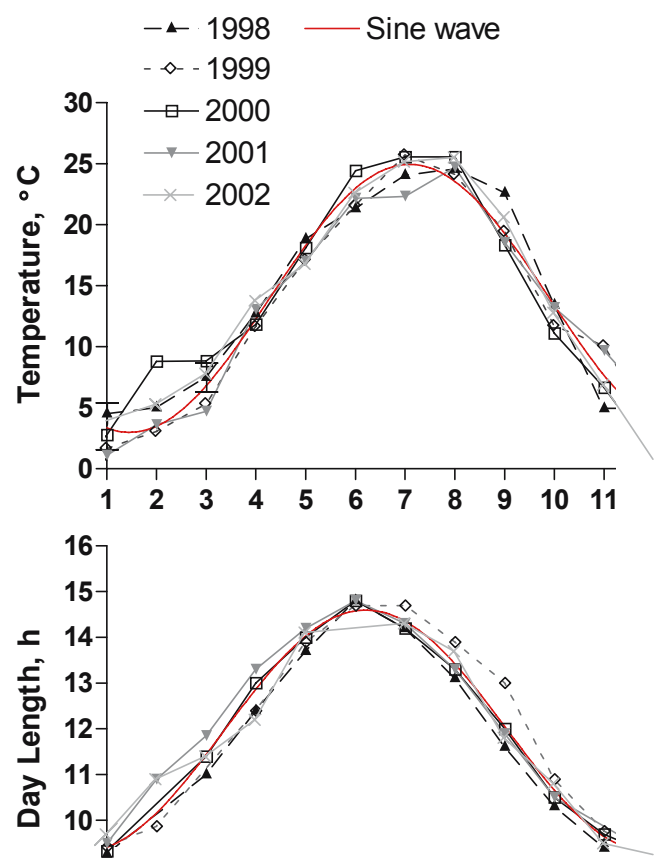

Fig 1 Environmental data over a period of 5 yrs overlaid with a sine wave non linear regression.

Die Umweltdaten zur Temperatur und Tageslänge über einen Zeitraum von 5 Jahren sowie die zugehörigen Sinuskurven entsprechend der nicht linearen Regressionsanalyse.

Table 1 Sine wave parameters for environmental and pasture variables.

Parameter der Sinuskurven für die Umweltfaktoren Temperatur $\left({ }^{\circ} \mathrm{C}\right)$ und Tageslänge $(h)$ zur Beschreibung der saisonalen Fluktuation der geprüften Variablen des Weideaufwuchses.

\begin{tabular}{lccccc}
\hline & Baseline & Amplitude & Frequency & Offset & $R^{2}$ \\
\cline { 2 - 6 } Temperature ${ }^{\circ} \mathrm{C}$ & $13.97 \pm 0.32$ & $10.98 \pm 0.30$ & $0.56 \pm 0.04$ & $3.80 \pm 0.10$ & 0.96 \\
Day Length $\mathrm{h}$ & $11.96 \pm 0.08$ & $2.64 \pm 0.07$ & $0.55 \pm 0.02$ & $4.40 \pm 0.09$ & 0.97 \\
CP \% & $16.86 \pm 0.21$ & $-2.95 \pm 0.29$ & $0.98 \pm 0.03$ & $0.91 \pm 0.25$ & 0.34 \\
DE Mcal/kg & $2.17 \pm-0.09$ & $-0.08 \pm 0.01$ & $0.99 \pm 0.04$ & $0.62 \pm 0.33$ & 0.23 \\
ADF \% & $32.87 \pm 0.23$ & $3.28 \pm 0.32$ & $0.95 \pm 0.03$ & $0.91 \pm 0.25$ & 0.34 \\
NDF \% & $37.99 \pm 0.31$ & $4.40 \pm 0.44$ & $0.99 \pm 0.03$ & $0.30 \pm 0.26$ & 0.33 \\
NSC \% & $12.43 \pm 0.28$ & $-2.42 \pm 0.41$ & $1.11 \pm 0.04$ & $-1.27 \pm 0.33$ & 0.15 \\
\hline$* 2 \pi / F=$ monthsfor l complete cycle & & & &
\end{tabular}




\section{Discussion}

The results of this study quantify relationships between critical environmental variables and pasture nutrient and energy concentration, as well as describing the patterns of these variables as they change from season to season. With increasing attention to carbohydrate fractions, the negative correlation of fiber with NSC is of interest. Quadratic relationships indicate periods when CP and DE were high in connection with specific temperatures. The seasonal patterns of all variable
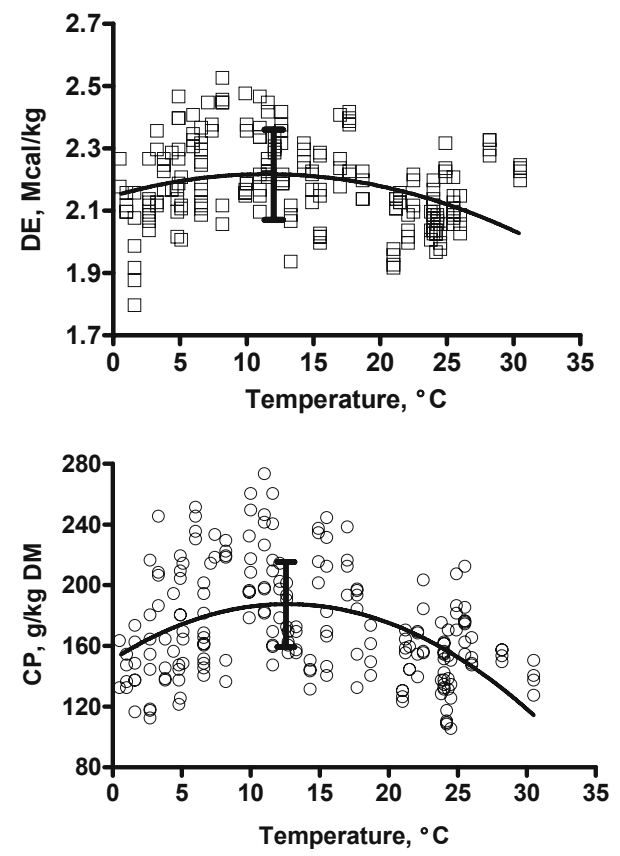

Fig 2 Digestible energy and CP are dependanMy view of this is that day length peaks prior to temp. This is important due to day lengths role in causing temp changes.

Verteilung der Gehalte des Aufwuchses an verdaulicher Energie (DE, Mcal/kg Trockenmasse) sowie an Rohprotein (CP, g/ kg Trockenmasse) in Abhängigkeit von der Umgebungstemperatur; Optima liegen bei $13{ }^{\circ} \mathrm{C}\left(D E=2,15+0,01 \times{ }^{\circ} \mathrm{C}-0,001 \times{ }^{\circ} \mathrm{C} 2 ; \mathrm{R} 2=0,11 ; \mathrm{CP}=\right.$ $\left.151+5,79 \times{ }^{\circ} \mathrm{C}-0,22 \times{ }^{\circ} \mathrm{C} 2 ; R 2=0,20\right)$. examined were well described with sine wave equations, providing a tool for those wishing to proactively manage their animals to optimize health and performance.

The sine wave described approximately $96 \%$ of the variation in TP and DL and was determined to be the best mathematical description of seasonal patterns in these variables. Due to the influence of TP and DL on pasture characteristics. A sine wave regression equation was applied to the pasture nutrient and energy data to model seasonal fluctuations in the given data.

Quadratic relationships between TP and CP and DE and NSC all indicate peak concentrations in the pasture at approximately $13^{\circ} \mathrm{C}$ which corresponds to mean spring and fall temperatures. Fiber content of the pasture reached a low point around $13^{\circ} \mathrm{C}$ in May (spring) and peaked at approximately $30^{\circ} \mathrm{C}$ in August (summer) and $0^{\circ} \mathrm{C}$ in January (winter). Fiber content decreased as non structural carbohydrates in the pasture increased. Fiber content in the pasture is directly related to ambient temperature and maturity of the plant (Arthington and Brown 2005). In summer and winter months the fiber concentration of the pasture is highest (Arthington and Brown 2005). The data collected at MAREC paralleled a similar study in New Zealand where fiber variables (NDF and ADF) were negatively related to NSC, ME, and protein (Machado et al. 2004).

Fluctuations in nutritive value of equine pastures have been implicated as a possible causal factor in several equine health related disorders (Kronfeld and Treiber 2005). One component of pasture nutritive value that is of interest in regard to pasture associated laminitis is NSC (Treiber 2005 and Byrd 2005). Since the agricultural revolution, grains and/or improved pastures have supplied abundant soluble carbohydrates to both humans and horses. These carbohydrates have been implicated in the incidence of pasture associated laminitis (Kronfeld and Treiber 2005). This study clearly illustrates the fluctuations in concentrations of NSC in the pasture and how it is influenced by TP and DL. Abrupt chan-

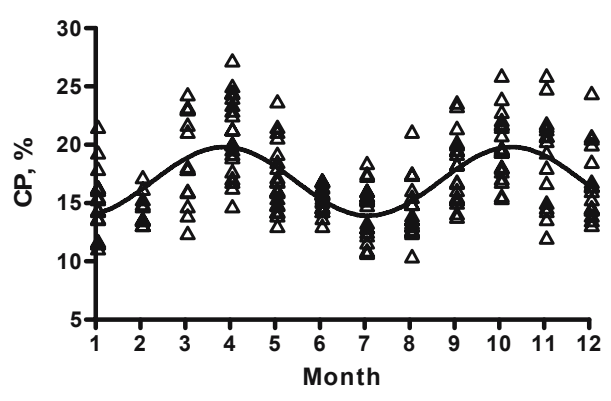

Fig 3 Seasonal fluctuations in nutritive value of pasture in Virginia represented by a sine wave Saisonale Fluktuation der Gehalte des Weideaufwuchses (bezogen auf die Trockenmasse) in Virginia an Rohprotein $(C P)$, neutralen Detergentienfasern (NDF), NichtGerüstkohlenhydraten (NSC) sowie verdaulicher Energie (DE) und die Charakteristik anhand der Sinuskurven.

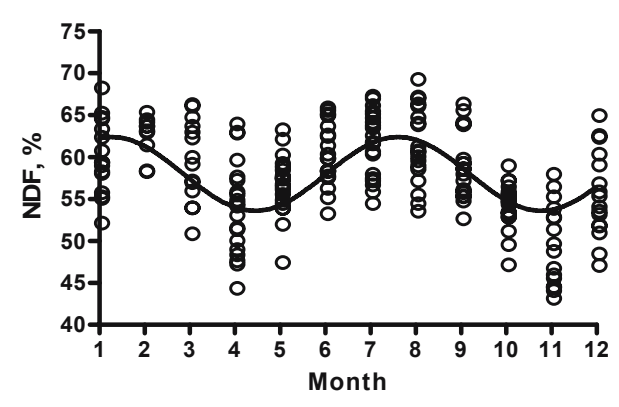

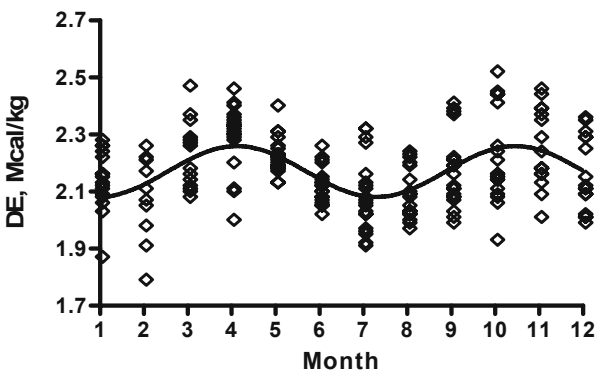

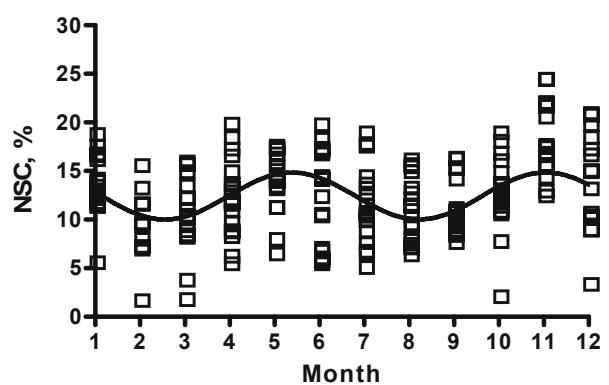


ges in these carbohydrate fractions may influence digestion, metabolism, and the risk for certain diseases in the horse such as colic (French et al. 2005) and laminitis (Longland et al. 1999).

An important objective of the research at MAREC is to understand both the animal and the pasture and the relationship between them. With this understanding the results of research are directly applicable in developing management strategies that avoid disease and enhance health and performance. Examples of this include:

Data indicating a need to supplement $\mathrm{Na}, \mathrm{Zn}$ and $\mathrm{Cu}$ throughout the year for both broodmares and growing horses and $\mathrm{Ca}$ and $\mathrm{P}$ for weanlings in the fall in Northern Virginia (Cubitt et al. 2004).

A management protocol that dictates breeding mares in May and June, foaling in April and May, and weaning in October. This protocol takes full advantage of the natural fluctuations of nutrients and energy in the pasture (Cubitt 2004)

Low pasture DE in the summer can usually be compensated by high intakes of pasture, unless intake becomes bulk limited through high contents of water or fiber-rare conditions in our region (Kronfeld et al. 1996).

\section{Conclusions}

In Northern Virginia, a large proportion of the horses are kept at pasture year round. For this to be a successful endeavor both economically and nutritionally it is imperative to characterize and understand seasonal fluctuations in nutritive value of the plants. An example of this is the effect of season onseasonal pattern of NSC. A number of environmental variables interact to cause elevated concentrations of NSC in the pasture. This coincides with large quantities of available pasture and is generally observed in the spring and fall. Horses prone to contracting laminitis should be closely monitored and intake of large quantities of pasture should be limited.

\section{References}

Arthington J. D. and Brown W. F. (2005): Estimation of feeding value of four tropical forage species at two stages of maturity. J Anim Sci. 83:1726-1731

Byrd B. M. (2005): Pasture components in laminitis: Carbohydrate analysis and variations in pasture components. In: Proc Waltham International Nutritional Sciences Symposium: Countermeasures to Laminitis, 42

Cubitt T. A. (2004): Environmental factors, pasture composition, growth rate and puberty in growing Thoroughbreds. M. S. Thesis, Virginia Polytechnic Institute and State Univ., Blacksburg
Cubitt T. A., Staniar W. B., Kronfeld D. S. and Harris P. A. (2004): Seasonal variation in forage composition in North Central Virginia. J Anim Sci. 82 (suppl 1), 96

Cubitt T. A. (2004): Environmental factors, pasture composition, growth rate and puberty in growing Thoroughbreds. M. S. Thesis, Virginia Polytechnic Institute and State Univ., Blacksburg.

Fick G. M., Wilkens P. W. and Cherney J. H. (1994): Modeling forage quality changes in the growing crop. In Fahey, George C. (ed.). Forage quality, evaluation and utilization. Madison, WI: Amer. Soc. oOf Agronomy, 757-795

French N. P., McCarthy H. E., Diggle P. J. and Proudman C. J. (2005): Clustering of equine grass sickness cases in the United Kingdom: a study considering the effect of position-dependent reporting on the space-time K-function. Epidemiol Infect. 133, 343-348

Hoffman R. M., Wilson J. A., Kronfeld D. S., Cooper W. L., Lawrence L. A., Sklan D. and Harris P. A. (2001): Hydrolyzable carbohydrates in pasture, hay and horse feeds: Direct assay and seasonal variation. J Anim Sci 79, 500-506

Kronfeld D. S., Cooper W. L., Crandell K. M., Gay L. A., Hoffman R. M., Holland J. L., Wilson J. A., Sklan D. and Harris P. A. (1996): Supplementation of pasture for growth. Pferdeheilkunde 12, 317 319

Kronfeld D. S. and Treiber K. H. (2005): Genetic and metabolic predictors of pasture laminitis: Opportunities for effective intervention. In: Proc Waltham International Nutritional Sciences Symposium: Countermeasures to Laminitis

Longland A. C., Cairns A. J. and Humphreys M. O. (1999): Seasonal and diurnal changes in fructan concentration in Lolium perenne: Implications for the grazing management of equine predisposed to laminitis. In: Proc. 16th Equine Nutr. Physiol. Soc., Ft. Worth, TX, 258-259

Machado C. F., Morris S. T., Hodgson J. and Fathalla M. (2005): Seasonal changes of herbage quality within a New Zealand beef cattle finishing pasture New Zealand Journal of Agricultural Research 48, 265-270

NAHMS (1998): Equine '98 study: Part iv: Reference of health management for horses and highlighted diseases, USDA:APHIS, Fort Collins, CO

Treiber K. H. (2005): Insulin resistance in equine laminitis. In: Proc Waltham International Nutritional Sciences Symposium: Countermeasures to Laminitis.

Wilson J. A., Kronfeld D. S., Cooper W. L. and Sklan D. (1997): Seasonal variation in the nutrient composition of northern Virginia forages. In: Proc. 15th Equine Nutr. Physiol. Soc., Ft. Worth, TX, 336-337

Tania Cubitt

5527 Sullivans Mill Rd

Middleburg, VA 20117

USA

tcubitt@vt.edu 